\title{
W kulturze wolności i konsumpcij. Rola wspókczesnego wychowania chrześcijańskiego w przezwyciężaniu kryzysu wartości
}

\section{In a Culture of Freedom and Consumption: The Role of Contemporary Christian Education in Overcoming the Crisis of Values}

\begin{abstract}
ABSTRAKT
Opracowanie podejmuje problem doświadczania wartości oraz roli wychowania chrześcijańskiego w przezwyciężaniu współczesnego kryzysu wartości w zakresie materializmu i problemów zwiqzanych z wartościq wolności. Zasadniczym przedmiotem badań była rola wychowania chrześcijańskiego w przezwyciężaniu problemów kryzysu wartości. Głównym celem badania było określenie roli wychowania chrześcijańskiego w przezwyciężaniu konfliktów wartości zawiqzanych $z$ materializmem i wolnościq. Próbowano odpowiedzieć na pytanie: w jakim zakresie i w jaki sposób Kościół wspiera jednostki w procesach refleksji oraz prób przełamywania własnego materializmu? Celem pomocniczym było zbadanie jakie doświadczenie wartości posiadaja badani studenci. Z tym celem wiqże się drugi przedmiot badań, jakim jest doświadczanie wartości. Wstępne badanie miało formę krótkiego sondażu, w ramach którego pytano
\end{abstract}

StOWA KLUCZOWE wartości, doświadczanie wartości, wychowanie chrześcijańskie, konsumpcjonizm, wolność, zmiana kulturowa

KEYWORDS

values, experience of values, Christian education, consumerism, freedom, cultural change

SPI Vol. 23, 2020/1

ISSN 2450-5358

e-ISSN 2450-5366 DOI: 10.12775/SPI.2020.1.004

Nadesłano: 10.01.2020 Zaakceptowano: 7.04.2020

Raporty z badań 
studentów Akademii Ignatianum w Krakowie o doświadczanie wartości. Drugi etap badań został zrealizowany metoda wywiadu fokusowego, uczestniczyły w nich dwie grupy studentek pedagogiki.

Badania pozwoliły wyodrębnić cztery wymiary doświadczania wartości, określić najważniejsze według studentek wartości we współczesnym wychowaniu chrześcijańskim oraz opisać rolę wychowania chrześcijańskiego w przezwyciężaniu problemów materializmu i realizacji wolności, zarówno tę pozytywnq, jak i negatywne jej aspekty. Najważniejsze postulaty dotyczqce wspierania młodych w doświadczaniu i wyborze wartości odnosza się do zmiany w komunikacji i postawie księży wobec wychowanka, zmiany celów wychowawczych w zakresie przygotowania wychowanka do doświadczeń aksjonormatywnych oraz inicjowania działań w zakresie różnych form doświadczania wartości.

\section{ABSTRACT}

The study addresses the problem of experiencing values and the role of Christian education in overcoming the contemporary crisis of values in terms of materialism and problems related to the value of freedom. The main subject of research was the role of Christian education in overcoming the problems of the crisis of values. The main aim of the study was to define the role of Christian education in overcoming conflicts of values associated with materialism and freedom. Attempts have been made to answer the following question: to what extent (and how) does the Church support individuals in reflections upon their own materialism and their attempts to overcome it? The auxiliary aim was to investigate what experience of value have surveyed students. The initial study took the form of a short survey in which students of the Jesuit University Ignatianum in Krakow were asked about their experience of values. The second stage of the research was carried out using the focus group method, involving two groups of pedagogy students.

The research allowed four dimensions of experiencing values to be distinguished, identifying the most important values according to female students in contemporary Christian education and defining the role of Christian education in overcoming the problems of materialism and the realization of freedom, both the positive and negative aspects of it. The most important postulates concerning supporting young people in experiencing and choosing values apply changes in priests' communication and attitude towards persons, changes in educational goals in the area of preparing young people for axionormative experiences and initiating activities in various forms of experiencing values. 


\section{Wprowadzenie}

Temat wartości doczekał się już wielu badań i licznych publikacji reprezentujących różne dyscypliny naukowe. Cyklicznie publikowane są też sondaże, które ukazują kierunki i tendencje zachodzących zmian w zakresie preferowanych wartości i potwierdzające problem, jaki z wartościami ma współczesna kultura.

Specyfikę niniejszego opracowania stanowi ujęcie wartości z punktu widzenia ich doświadczania w odniesieniu do wychowania chrześcijańskiego. Podjęte najpierw badanie dotyczące sposobów doświadczaniem wartości prowadzi następnie do pytania o rolę wychowania chrześcijańskiego w przezwyciężaniu kryzysu wartości w poszczególnych wymiarach ich doświadczania. Uwaga została skupiona na dwóch wartościach kluczowych dla współczesnego kryzysu wartości. Są to wartości materialne oraz wartość wolności rozumianej jako wyzbycie się ograniczeń i niepodejmowanie odpowiedzialności.

Podstawą opracowania są badania przeprowadzone wśród studentów Akademii Ignatianum w Krakowie (AIK). Przedmiotem badań było samo doświadczanie wartości oraz rola wychowania chrześcijańskiego w przezwyciężaniu problemów kryzysu wartości w zakresie materializmu i wolności. Badania $\mathrm{w}$ formie wywiadu fokusowego przeprowadzone zostały w dwóch grupach studentów AIK w grudniu 2019 roku. Grupy liczyły 8 i 9 osób, były to kobiety, studentki kierunku pedagogiki drugiego stopnia studiów stacjonarnych. Wywiady fokusowe poprzedził krótki sondaż, przeprowadzony wśród losowo wybranych studentów, w ramach którego 38 osobom zadano pytanie o doświadczanie wartości.

\section{Doświadczanie wartości}

Sposobów definiowania wartości jest wiele, a bogactwo świata wartości nie ułatwia zadania polegającego na wyczerpującym określeniu, czym one są (por. Chałas 2003: 18). Zwykle przywoływana definicja wiąże się z przyjmowaną przez badacza teorią. Interesujące podejście w praktyce nauk społecznych, a zwłaszcza w pedagogice, wiąże się z pytaniem o możliwości doświadczania wartości.

Wartości w życiu człowieka mają związek z jego wyborami, z jakością jego egzystencji (Chałas 2003: 29). Doświadczanie wartości 
wydaje się dla wielu abstrakcyjnym hasłem. Nie jest to łatwe doświadczenie. Ma tu znaczenie też sama wartość, bowiem to od rodzaju wartości zależy jak można jej doświadczać. Czym innym jest doświadczanie piękna, należącego do wartości estetycznych, czym innym doświadczanie sprawiedliwości, która lokuje się wśród wartości moralnych. Sonda przeprowadzona wśród studentów Akademii Ignatianum w Krakowie pokazała różnorodność w rozumieniu czym wartości są i w samym podejściu do nich. Prezentowane przez badanych intuicyjne rozumienie, czym są wartości i jak można ich doświadczać, pokrywa się z teoretycznymi ujęciami etyków, filozofów czy pedagogów, definiujących albo klasyfikujących różne rodzaje wartości, czy też piszących o ich funkcjach w życiu człowieka.

Badani zapytani o to, jak można doświadczać wartości, mówili o trudnościach w nazywaniu czy ujmowaniu wartości i o warunkach, jakie muszą być spełnione, by o takim doświadczaniu można było mówić: Wartości nie da się doświadczać, sq zbyt subiektywne. Można je w perwien sposób przeżywać. Potrzebna jest świadoma refleksja, namysł: Sa perwne doświadczenia, w których można dostrzec ten aspekt wartości. Ale dopiero wórwczas, gdy zaczniemy opisy wać w sposób wartościujacy. To trudny temat. Fakt występowania różnych stopni trudności, wyrażonych przez udzielających odpowiedzi, zgadza się ze spostrzeżeniem Czesława Matusewicza. Według niego wartości „różnicują dążenia ludzi - są jednym z determinant różnorodności struktur psychicznych i dążeń jednostkowych” (Matusewicz 1975: 44). Toteż sposób i intensywność przeżywania wartości jest różna dla poszczególnych osób.

Badani odwoływali się do codziennych wyborów jako czynności związanej z doświadczaniem wartości. Różna jednak była ocena owego doświadczania. Niektórzy mówili że jest to doświadczenie wyjątkowe, niecodzienne: Tak na co dzień ich chyba nie doświadczam. Dopiero gdy przyjdzie jakis trudny wybór i nie wiem co zrobic. Wtedy zaczynam się gtębiej zastanawiać. To wtedy, wedtug mnie, wartości zaczynaja brać udziat w tym moim decydowaniu.

Inni uważali, że wprawdzie podejmują wybory, ale nie reflektują głębiej nad wartościami: Na co dzień nie myślimy w takich kategoriach. Przeżywamy, ale nie myśli się o wartościach jako takich, o ich doświadczaniu. Dopiero takie pytanie wywotuje refleksje, co jest w moim życiu wartościq, co się liczy ostatecznie. 
Jeszcze inni twierdzili, że jest to ich codzienne doświadczenie: Nieustannie ich dosiwiadczam, to moje codzienne wybory, nawet te najprostsze - czy pójsć do koleżanki, do biblioteki czy do sklepu. To te codzienne mate wybory i malutkie spory wartości $[. .$.$] to ja przecież decyduje co$ jest ważniejsze akurat dla mnie. Można przypuszczać, że są to osoby bardziej refleksyjne, które być może uczestniczą albo uczestniczyły w jakiejś formie formacji. W końcu byli i tacy, którzy wprost twierdzili, że życie człowieka kształtują wybierane przez niego wartości, a ich wybór określa rodzaj zaangażowania i podejmowanych wysitków. Ta realizacja, dążenia są także formą doświadczania wartości. Cele życiowe cztowieka określaja wartości. To może być rodzina albo Bóg. Albo ktoś się chce poświęcić pracy w wolontariacie, [...] albo podobnie pracy nauczyciela. Ktoś inny wybiera karierę sportowca, to te żjest pewna wartość, którq realizuje i doświadcza jej. Podobnie o przeżywaniu i doświadczaniu wartości pisał Stanisław Kowalczyk: „wartością jest to, co jest przedmiotem pożądania, co jest upragnione przez człowieka, co jest celem jego zabiegów” (2006: 67) czy Mieczysław Łobocki: „to wszystko, co uchodzi za ważne i cenne dla jednostki i społeczeństwa oraz jest godne pożądania, co łączy się z pozytywnymi przeżyciami i stanowi jednocześnie cel dążeń ludzkich” (1993: 125).

Badani zwracali uwagę na społeczne oddziaływanie innych i na uczenie się wartości. Czyjś wybór, protest, działanie mogą się stać znakiem, świadectwem, pociągającym przykładem. Studentka wyjaśnia: Wrelacjach z innymi, gdy ktoś wybiera dobro i ja jestem tego świadkiem - to prawdziwe doświadczenie, bo robi wrażenie, dostaje taki sygnat, znak... Sama się wtedy zastanawiam co jest ważne.

Podobnie oddziaływanie innych może nieść zagrożenie dla wartości w wymiarze społecznym $\mathrm{i}$ to jest też rodzaj ich doświadczaniapoprzez rozpoznanie zagrożenia albo utraty: To doświadczenie może być pozyty wne albo negatywne. Bo mogę doświadczać, że moje wartości sq zagrożone. Tak jakjest teraz, gdy na przyktad zagrożona jest demokracja.

Część osób badanych odwoływała się do określonych wartości, zauważając, że sposób ich doświadczania może być różny w zależności od określonej wartości: Myślę, że niektórych wartości doświadcza sie troche od święta. Piękna doświadczam, gdy ide do galerii, na wystawę. Inna badana zauważyła: Pytanie chyba powinno być zadane inaczej. Wartości sq bardzo, bardzo różne. Trzeba zapytać o konkretnq wartość. Na przyktad wolność, wartość wolności. Czy jej doświadczam? Ja o niej 
nie myśle, bo ja raczej posiadam. Nikt mi jej nie zabiera, mam zaperwnione podstawowe środki do życia, moge więc studiować. Perwnie gdyby mi tej wolności mojej, na moja miare, zabrakto, to mocno bym tego dośrwiadczata jako braku.

Różne formy doświadczania wartości w ujęciu studentów łączą się w pełniejszy obraz, na który składają się refleksje i przemyślenia w kontekście różnych doświadczeń, obserwacje i inspirowanie się innymi, doświadczanie trudu własnych wyborów w kontekście wartości, a także poczucie zagrożenia bądź nawet ich utraty.

Sposoby doświadczania wartości wskazane przez badanych zostały zebrane i usystematyzowane. Poniższa rycina (Ryc. 1) obrazuje schematycznie różne wymiary doświadczania wartości w ujęciu badanych. 
Ryc. 1. Wymiary doświadczania wartości w uięciu badanych studentów
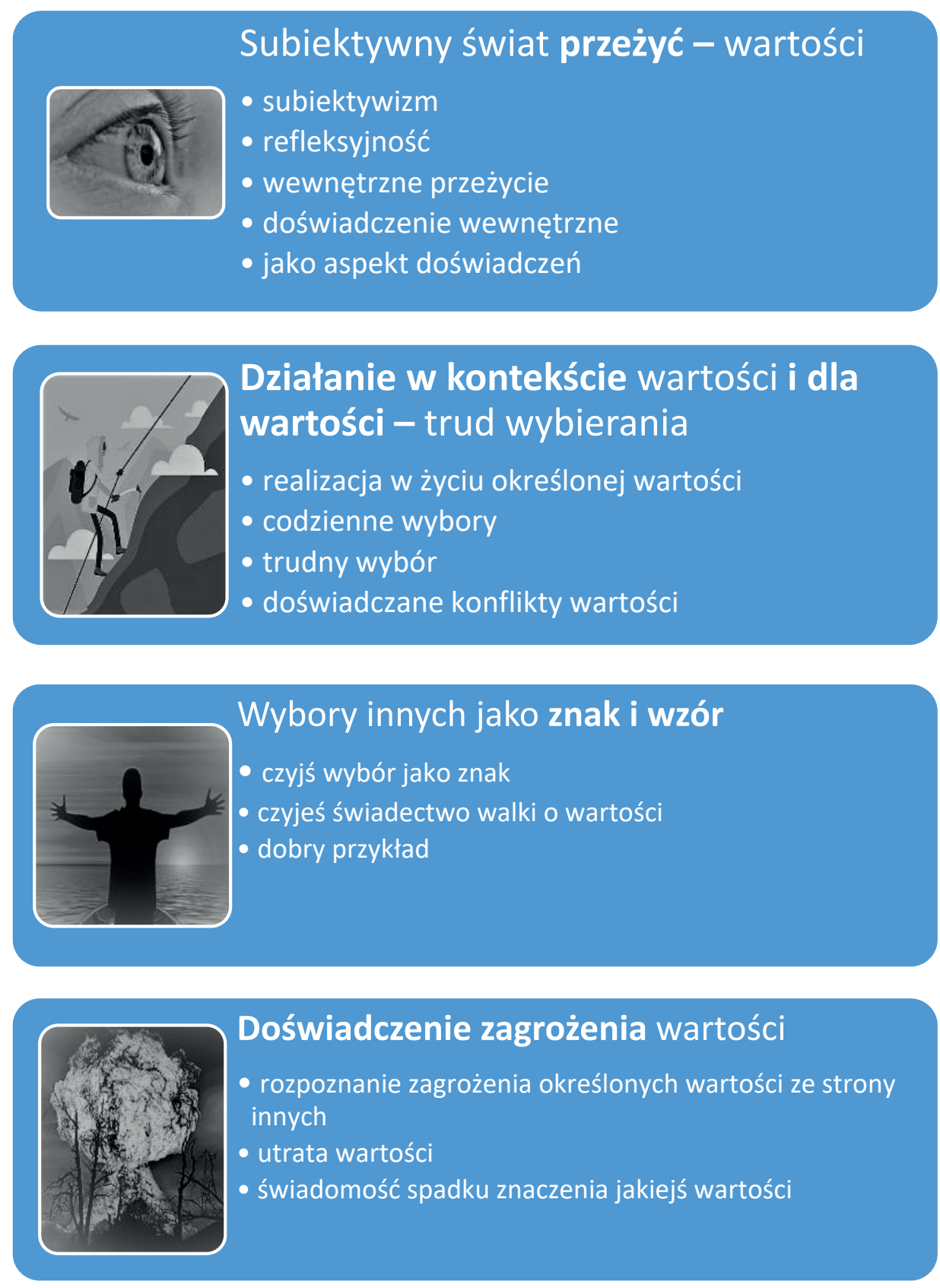
Zależności pomiędzy wyodrębnionymi sposobami doświadczania wartości wydają się być wyraźne, realizacja wartości dokonuje się głównie w wyborach i będących ich naturalną konsekwencją działaniach. A te wypływają z subiektywnego świata przeżyć i refleksji, inspirowanego szeroko rozumianym działaniem innych, zarówno pozytywnym (znak, przykład, świadectwo), jak i negatywnym, odczytywanym jako zagrożenie dla wartości (por. Ryc. 2).

Ryc. 2. Różne wymiary doświadczania wartości i zależności pomiędzy nimi

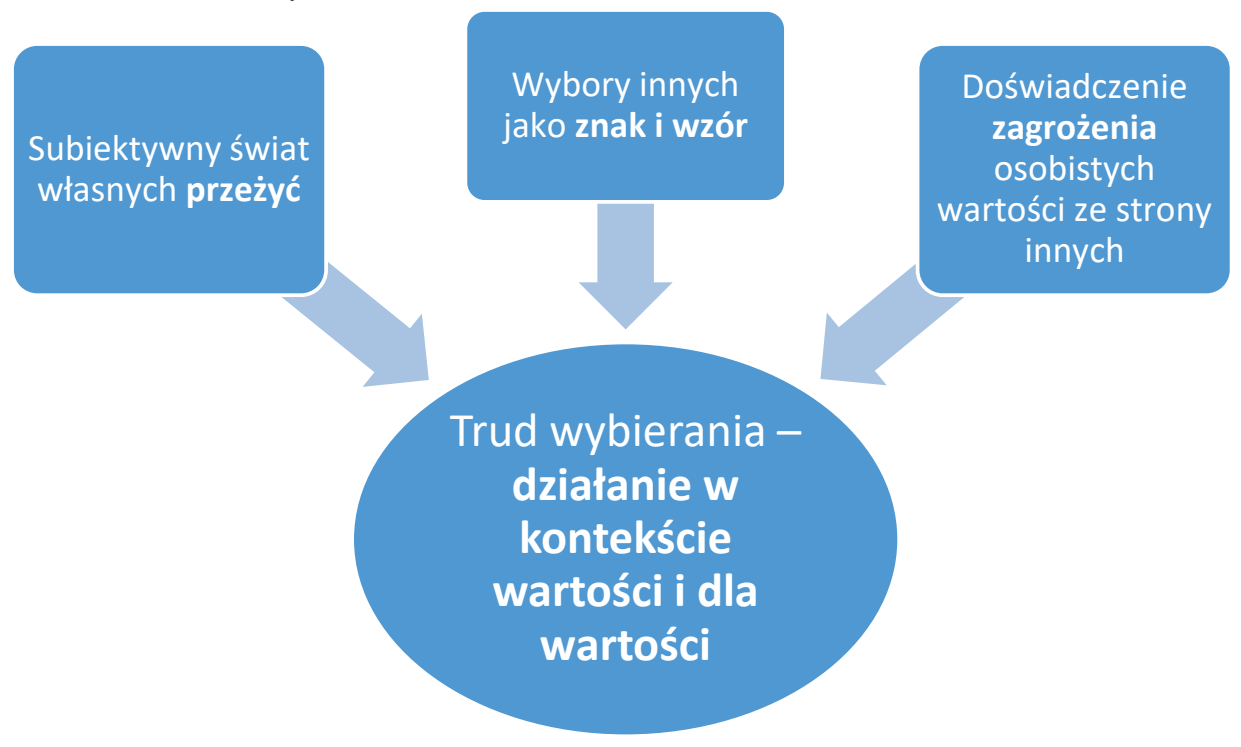

\section{Człowiek w kulturze wolności i konsumpcii}

Opublikowany w lutym 2019 roku komunikat z badań CBOS (CBOS 2019: 2), dotyczących wartości, którymi Polacy kierują się w życiu, ukazuje na szczycie hierarchii „szczęście rodzinne” (80\% badanych), przed „zachowaniem dobrego zdrowia” (55\%) i „spokojem” (48\%). Nie ma nic zaskakującego w pierwszej ze wskazanych wartości, gdyż rodzina niezmiennie cieszy się największym uznaniem, niezależnie od grupy wiekowej i mijającego czasu, chociaż zachodzą w niej samej istotne zmiany. Symptomatyczne wydaje się sformułowanie ujmujące nie samą rodzinę, ale wiążące ją z osobistym szczęściem. Znacząca jest trzecia wybierana wartość, czyli „spokój”. Sondaż TNS Polska przeprowadzony w 2013 roku wskazywał 
niezmiennie wysoką wartość rodziny, ale zarazem wzrost znaczenia wartości materialnych, pieniędzy, a także sukcesów w pracy, uznania otoczenia, zdrowia i „dużej ilości wrażeń” (TNS Polska 2013: 3). W grudniu 2019 roku zapytano badanych o potwierdzenie przysłowiowego powiedzenia „pieniądze szczęścia nie dają”. Tylko 7\% badanych całkowicie zgodziło się z twierdzeniem, a pomiędzy głosami potwierdzającymi i zaprzeczającymi wystąpiła równowaga (47\% 46\%; KANTAR 2019: 6) ${ }^{1}$.

Zmieniający się na naszych oczach świat nie sprzyja trwałości kultury, tradycji, wyznawanych norm i wartości. Wprawdzie rodzina od zawsze jest wartością nadrzędną, ale rośnie znaczenie wartości materialnych i „wolnościowych”, które ją zmieniają. Głębsza analiza ukazuje, że pożądana stała się taka „wolność, która wydaje się być zaprzeczeniem wartości. Andrzej M. de Tchorzewski, bazując na rozróżnieniu Tadeusza Ślipki, przedstawił trzy wymiary wolności: psychologiczną, naturalną i społeczną. Osiągnięcie lub zachowanie każdej z nich wiąże się z wysiłkiem osoby, którego współczesna kultura popularna nie zakłada i nie przewiduje (Tchorzewski 2017: 206-207)2. Ważnym celem dla współczesnego człowieka staje się samorealizacja rozumiana jako osiąganie bezpieczeństwa finansowego (Zawadzka 2006: 64). To bezpieczeństwo łączy się właśnie z drugą kluczową dzisiaj wartością - z wolnością rozumianą jako wyzwolenie się z wszelkich ograniczeń. Janusz Mariański zauważył, że „problemem najbardziej newralgicznym w społeczeństwie obywatelskim i demokratycznym jest pojmowanie wolności, autonomii i samorealizacji w kontekście nieograniczonego korzystania z możliwości wyboru" (1998: 85). Autor przywołał stwierdzenie Zygmunta Baumana, że kultura ponowoczesna gloryfikuje wolność, ale koszt tego jest wysoki. Człowiek wolny od ograniczeń płaci cenę, jaką jest „tortura niepewności, zagubienia” (Mariański 1998: 85). Zbyszko Melosik

$17 \%$ - zdecydowanie się zgadzam; 40\% - raczej się zgadzam; $12 \%$ - zdecydowanie się nie zgadzam; $34 \%$ - raczej się nie zgadzam.

2 Wolność psychologiczna rozumiana jako „autonomiczna siła człowieka kierująca go ku poznawaniu samego siebie i otaczającego go świata”; wolność naturalna „dotyczy osobowej godności człowieka, która budowana jest na wpisanym w jego rozumną naturę obiektywnym ładzie moralnym”; na wolność społeczną składają się m.in. formy takie, jak „wolność sumienia i religii, wolność myśli i słowa, wolność obywatelska” (Tchorzewski 2017: 207). 
i Tomasz Szkudlarek zauważyli zarazem, że poczucie wolności współczesnego człowieka wcale się nie zmieniło, człowiek wciąż marzy o wolności i wcale nie czuje się wolny (2010: 91). Jak zaznaczył dalej Mariański, „sprywatyzowana wolność” chce być samowystarczalna, jednak nie potrafi nadać sensu ludzkiemu życiu ani uzasadnić jego celowości (por. Mariański 1998: 86).

Tak pojmowana wartość wolności idzie w parze $\mathrm{z}$ wartościami materialnymi. George Ritzer, opisując przeobrażony ekonomicznie i popkulturowo Magiczny świat konsumpcji3 (2004: 23-24), ,skatalogował" nowe formy konsumpcji. Na jednym z pierwszych miejsc umieścił „świątynie konsumpcji”, wielkie centra handlowe: „galerie” i „parki” rozrywki oferujące nie tylko wszelkie towary, ale także usługi oraz formy spędzania wolnego czasu.

Rewolucja w zakresie środków, sposobów i rozmaitych form konsumpcji już dawno zmieniła także polską rzeczywistość. Gdy pięć lat temu jedna $z$ magistrantek Akademii Ignatianum w Krakowie badała formy spędzania czasu wolnego przez młodzież gimnazjalną, badani dopisywali w kategorii „Inne”: „robienie zakupów”, dając do zrozumienia, że badaczka nie uwzględniła w ramach przygotowanej kafeterii tej formy.

Ritzer doszedł do wniosku, że konsumpcjonizm przyniósł głębokie zmiany w społecznych relacjach. Autor opisuje kupujących jako krążących po centrach handlowych „zombi”, niezwracających uwagi na innych ludzi mimo tłumu (2004: 302-303). Najgłębsza bowiem relacja, ta która porusza człowieka, zachodzi tu między nim, czyli konsumentem, a nabywanym towarem. To nabywane przedmioty wywołują pragnienie, radość, wzruszenie, zadowolenie, szczęście. Ludzie przybywają tu w celach praktykowania „religii konsumenckiej” (Ritzer 2004: 23-24). Schelerowski podział na wartości hedonistyczne, utylitarne, witalne, duchowe i religijne zdaje się być zdominowany przez konsumpcję, a w konsekwencji przez materializm. Wszystkie szczeble powyższej hierarchii „zyskały" nowy, zmaterializowany wymiar, otrzymały konsumpcyjny przydatek i konsumencki serwis. Mówi się nawet, jak zauważył Mariański, o „rynku wartości i norm moralnych” (2004: 333).

3 Wydanie oryginalne w języku angielskim było zatytułowane: Enchanting a Disenchanted World: Revolutionizing the Means of Consumption. 


\section{Najważniejsze wartości we współczesnym wychowaniu chrześcijańskim}

Mówiąc o chrześcijańskim wychowaniu i edukacji, można mieć na myśli edukację religijną realizowaną $\mathrm{w}$ formie katechezy, edukację opartą na chrześcijańskiej koncepcji wychowania albo szeroko rozumiane (poza katechezą) oddziaływania Kościoła. Szczególnymi instytucjami realizującymi wychowanie chrześcijańskie są rodzina, Kościól, szkoła katolicka.

Rodzina jest wprawdzie najważniejsza, ale jak zauważyła Maria Miczyńska-Kowalska, „w coraz większym stopniu w przekazywaniu wartości młodemu pokoleniu uczestniczą inne grupy pierwotne niż rodzina, jak również grupy wtórne" (2010: 76). W niniejszym opracowaniu skupię się na oddziaływaniach Kościoła. Misja Kościoła, rozumiana $\mathrm{w}$ kategoriach nauczania i wychowywania, była zawsze traktowana strategicznie jako kluczowa (por. Niewęgłowski 2005: 21; Dziekoński 2000: 11). Kościół od początku pełnił funkcję wychowawczą w zakresie kształtowania „moralnej postawy człowieka”, zaznacza Alina Rynio (2017: 377). Co więcej, zgodnie z soborowym Dekretem o wychowaniu chrześcijańskim Gravissimum educationis, jego misja obejmuje wszystkich ludzi i świat, w którym żyją (Dekret o wychowaniu chrześcijańskim..., nr 3; por. Wajsprych 2009: 14).

O wartościach w kontekście wychowania chrześcijańskiego rozmawiałam $\mathrm{z}$ dwiema grupami studentek pedagogiki $\mathrm{w}$ ramach wywiadu fokusowego. Na wprowadzające, ogólne pytanie o to, jakich wartości brakuje w dzisiejszym świecie, odpowiedzi badanych były bardzo podobne. Nie powtarzały one tych samych słów, jednak wymieniały wartości określające relację pomiędzy ludźmi: empatię, zrozumienie, szacunek, życzliwość, współczucie, tolerancję, miłość, poświęcenie dla drugiego człowieka, rodzinę, czas. Wskazywane wartości jako szczególnie dzisiaj pożądane dobrze ilustrują problemy w relacjach międzyludzkich. Jedną z przyczyn może być współczesny problem materializmu, który sprawia, że cierpią relacje interpersonalne. Innym czynnikiem może być głęboki konflikt polityczny, który antagonizuje polskie społeczeństwo i rzutuje tym samym na więzi społeczne.

Kluczowymi wartościami w wychowaniu, według biorących udział w badaniu studentek pedagogiki, są: rodzina, miłość, miłość i troska, 
miłość i zrozumienie, okazywanie miłości i dawanie bezpieczeństwa, wartości religijne, Bóg, szacunek i tolerancja, rozmowa. Badane podkreślały kluczowe w kontekście wychowania znaczenie rodziny, którą zakwalifikowano do najważniejszych wartości. Zarazem rodzina została przywołana również wśród tych wartości, których obecność jest niewystarczająca lub których braku odczuwa się najbardziej.

Można zauważyć, że wartości wskazywane w odpowiedzi na pytanie o te, których w dzisiejszym świecie brakuje, w dużej mierze pokrywały się z tymi, które są kluczowe w wychowaniu. Dotyczą one relacji międzyludzkich. Sygnalizuje to problem polegający na tym, że badani młodzi odczuwają braki w zakresie wartości realizowanych w relacjach międzyosobowych.

Pytanie o wartości, których nie może zabraknąć w chrześcijańskim wychowaniu, wywołało refleksje i dyskusję. Przywoływane wartości i treści można sklasyfikować w trzech grupach (por. Ryc. 3). W pierwszej znalazły się te wartości, które są niewystarczająco obecne: miłość do Boga i bliźnich, miłość i przebaczenie oraz wiara. W trzeciej grupie znalazły się dwie zagrożone wartości: poszanowanie życia od poczęcia do śmierci oraz odpowiedzialność za zagrożone środowisko. Natomiast druga grupa wartości, których nie może zabraknąć w chrześcijańskim wychowaniu, okazała się najliczniejsza do niej zaliczono te wartości, których wydaje się brakować: szacunek do drugiej osoby, tolerancja, głęboka rozmowa, otwarcie na świat i na autentyczne wartości innych ludzi, odwaga w konfrontacji z problemami dzisiejszego świata, mądra wiedza, wiedza i mądrość, rozeznanie tego, co jest dobre, a co złe.

Interesująca rozmowa wywiązała się w odniesieniu do wartości określonej jako: wiedza i mądrość. Badane zastanawiały się, jaka wiedza jest ważna i zgodnie doszły do wniosku, że potrzeba mądrej wiedzy, chodzi o profesjonalizm, o to, by chrześcijanin nie powtarzat banatów albo uprzedzeń, aby gtęboko spogladat na rzeczywistość, i tę spoteczna i... na świat w ogóle. 
Ryc. 3. Wartości, których nie może zabraknqć w chrześcijańskim wychowaniu w opinii badanych studentów
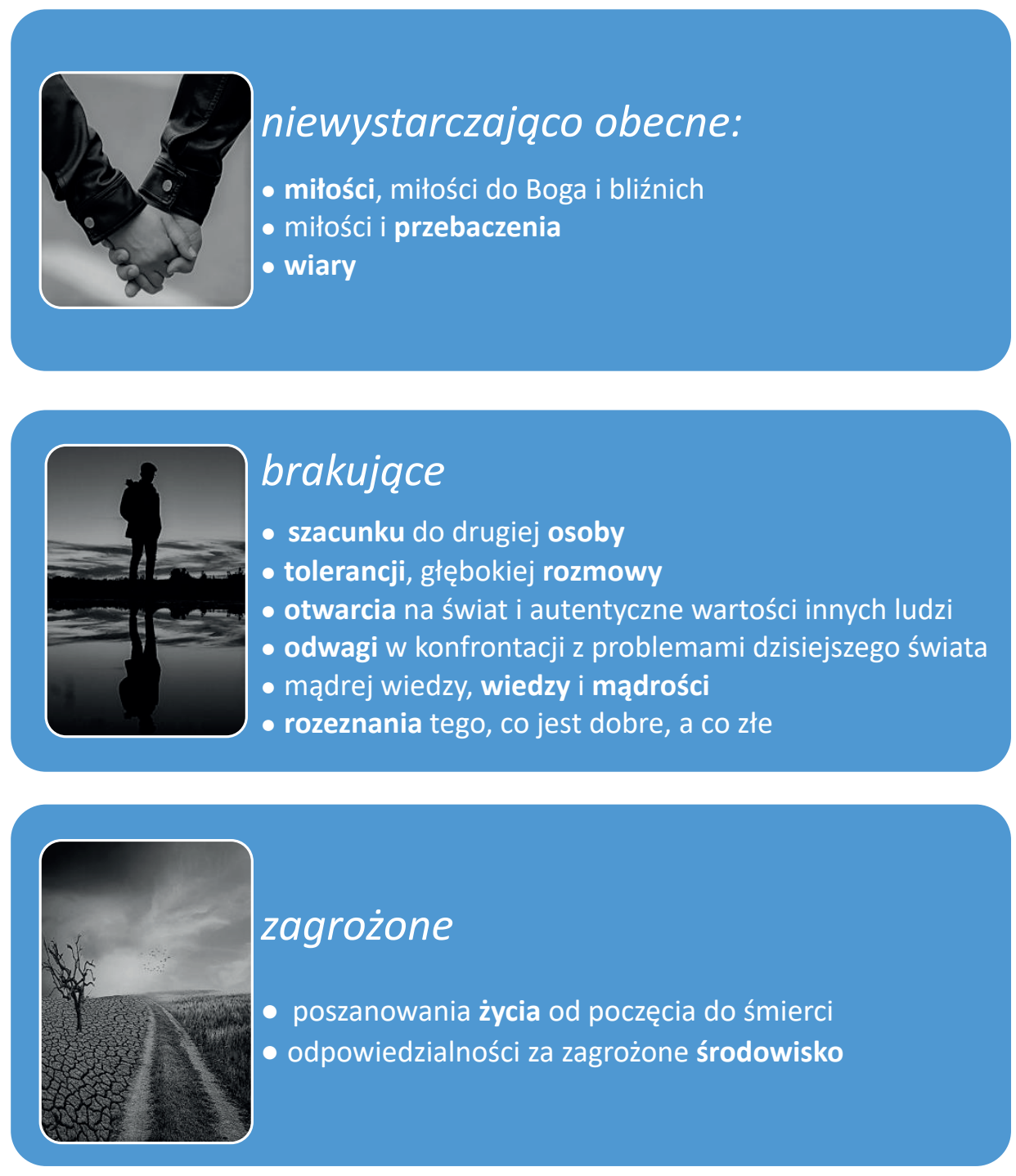


\section{Rola wychowania chrześcijańskiego w przezwyciężaniu problemów materializmu i realizacii wolności}

Pytanie dotyczące wprost roli Kościoła w przekazie wartości poprzedziła dyskusja na temat problemów współczesnego świata ze zrozumieniem i realizacją wartości wolności oraz kwestii związanych z materializmem. $Z$ racji ograniczonej objętości niniejszego opracowania dyskusja ta nie będzie tutaj omawiana. Aby zapytać o rolę Kościoła w przekazywaniu wartości, zastosowano technikę zdań niedokończonych. Badani mieli kontynuować wypowiedź rozpoczynającą się od słów: „Kościół w zakresie wartości...”. Wywołało to ożywioną dyskusję, badane podawały różne przykłady zaangażowania Kościoła w przekaz wartości, ale także wskazywały na niekonsekwencję w działaniach podejmowanych przez osoby duchowne. Kolejne pytanie miało za cel ukazać rolę wychowania chrześcijańskiego prowadzonego przez Kościół w zakresie przezwyciężania problemów związanych z realizacją wolności i ze współczesnym materializmem. Wypowiedzi studentek i rozwinięta dyskusja stanowiły kontynuację wcześniejszej rozmowy, dlatego zostaną omówione łącznie.

Podejmując kwestię roli Kościoła i wychowania chrześcijańskiego w przekazywaniu wartości oraz przezwyciężaniu współczesnych kryzysów wartości, badane formułowały bardzo różne opinie. Ich wypowiedzi zostały podzielone na te, które doceniają i wysoko oceniają tę rolę, na wypowiedzi neutralne i ambiwalentne, oraz na te krytyczne, negatywnie postrzegające rolę Kościoła w tej materii.

Wypowiedzi wysoko oceniające rolę Kościoła w przekazywaniu wartości oraz przezwyciężaniu współczesnych kryzysów wartości wskazywały na Kościół jako „fundamentalne źródło”, źródło i drogowskaz. Opisywały Kościół, jako ten, który „niesie wartości”, „przechowuje w tradycji”, ,wskazuje prawdziwe wartości i daje o nich świadectwo”, jest przewodnikiem, jest „świadkiem Jezusa”, „niesie ewangelię, która jest skarbnicą wartości”. Badane określały kluczowe wartości, które niesie Kościół: Kościót w zakresie wartości stawia przede wszystkim na okazywanie mitości Bogu oraz drugiemu cztowiekowi. Wskazywały także sposób oddziaływania w kontekście kryzysu wartości: Prawo mitości Boga i bliźniego, praktykowane w Kościele, przeciwstawia sie materializmowi. 
Badane odwoływały się również do wpływów ogólnokulturowych: Kościót jest na perwno takim przerwodnikiem, trudno mi nawet wyobrazić sobie jakim bylibyśmy spoteczeństwem, gdyby nie Kościót. Wiara, tradycja chrześijanska, to wszystko, co gdzies tam w gtębi siebie nosimy, nawet jeśli nie jesteśmy jakoś specjalnie wierzacy. To jest pewna kultura, perwna postawa, pewien sposób zachowania się. Myślę, że Kościót daje nam bar$d z o d u \dot{z} 0$.

Przywoływano też wpływ wybranych osób, opiekunów grup formacyjnych, rekolekcjonistów, duchownych prowadzących blogi. Ważnym świadkiem i przewodnikiem dla niektórych jest obecny papież. Jedna z badanych mówiła: Dla mnie takim przerwodnikiem jest papież Franciszek. Lubie go stuchać, bo jest taki prawdziwy, naturalny, on gtosi erwangelię, Dobra Nowinę dla różnych ludzi. To mi przypomina nawet troche Jezusa - on nie wyklucza, tak jak Jezus, a krytykuje hipokryzje, brak wrażliwości na innych. Jak kiedyśpowiedziat, że prawdziwy chrześcijanin nie może nie znać swoich sąsiadów, to ja się przejętam. To jest świadectwo i to jest kierunkorwskaz. Tak, w takim znaczeniu Kościót jest przewodnikiem, przybliża wartości.

Oceny przeciwstawne były pełne krytyki wobec pewnych zachowań duchownych. Badane twierdziły, że księża wypowiadaja sie nieodpowiedzialnie, wypowiadaja się na tematy polityczne, zamiast jednoczyć - dziela, etykietuja, nie szanuja ludzi (np. gtosujacych na innq partie, np. jak ktoś ma tatuaż). Osobne wypowiedzi dotyczyły materializmu. Badane zauważyły, że jest to szerszy problem i dotyka także części duchownych: Kościót wydaje się mieć problem z materializmem, zbyt dużo jest przyktadów takich zachowań.

Pośrodku lokowały się wypowiedzi ambiwalentne, neutralne, albo po prostu próbujące zrozumieć zaistniałe problemy.

\section{Niekonsekwencje}

Badane zwracały uwagę, że Kościót w zakresie wartości daje czasem sprzeczne komunikaty (kodowanie in vivo). Przywołano przykłady głoszenia nauki o godności każdego człowieka i zarazem okazywania braku szacunku w stosunku do określonych grup ludzi, na przykład LGBT. Badane doszły do wniosku, że czasem brakuje w działaniach Kościoła konsekwencji. Kościót przez swoja dziatalność na rzecz ludzi biednych, w trudnej sytuacji, pokazuje co jest prawdziwa 
wartościq - cztowiek, a nie materia. Chociaż z drugiej strony sq duchowni, którzy też sq materialistami, oni daja antyświadectwo. Według badanych Kościół bywa niekonsekwentny, naucza o ubóstwie i wartościach duchowych, ale duchowni cenią dobra materialne i domagają się pieniędzy od wiernych.

\section{Zależy od konkretnych osób}

To, jak Kościół pomaga w przezwyciężaniu problemów dotyczących wartości, w dużej mierze zależy od osoby, od konkretnego księ$d z a$. Badane zauważyły, że sytuacja jest bardzo zróżnicowana i zależy od środowiska: To zależy kogo sie stucha, na przyktad tu w Krakowie sq takie parafie, jak dominikanie czy jezuici, można porwiedzieć że to sq przewodnicy, ale w matych miejscowościach, gdzieś w wioskach, ludzie po prostu takich przewodników nie maja. Trafiaja na księży, którzy czasem nie sa dobrymi nauczycielami.

Oprócz oceny roli Kościoła studentki podjęły także próby wyjaśnienia zjawiska wsparcia bądź jego braku. Wskazywano na uwarunkowania oddziaływania Kościoła w zakresie wartości. Zauważono, że Kościót pomaga, jeśli się jest wierzacym, a zatem czynnik osobistej wiary ma tu duże znaczenie. Dyskutowano nad przyczynami, spierano się o zakres zjawiska, o ocenę. Interesujące były próby określenia własnej postawy i wpływu samych wierzących na przedstawiane sytuacje.

\section{Wszyscy jesteśmy materialistami}

Były też próby głębszego spojrzenia na problem. Niektóre studentki starały się zrozumieć księży, nie oceniać ich surowiej niż innych ludzi, a nawet zauważyły, że „materialista” też może pomagać. Ja myśle że ten dzisiejszy świat, ten masz materializm, którego wszyscy w jakiś sposób doświadczamy... no, jesteśmy materialistami, kto nie lubi iść na zakupy i kupić sobie coś fajnego? Każdy, i księża tak samo, wszyscy to widzq... Myśle jednak, że jest wielu duchownych, którzy pomagaja swoim świadectwem, swoja postawa, nawet tym, że poświęcili swoje $\dot{z} y-$ cie, $\dot{z}$ e stǘq innym, to jest prawdzi iwe świadectwo i to jest znak. 


\section{Nie można oceniać powierzchownie}

Inne osoby zauważyły, że nie można oceniać powierzchownie, zatrzymywać się na negatywnych przykładach, nawet jeśli się powtarzają. My jesteśmy przyzwyczajeni, że Kościót gtosi najwyższe wartości, takie jak Bóg, mitość, cztowiek, jego życie czy prawda, i dlatego już tego nie dostrzegamy, bo to sie wydaje takie oczywiste, widzimy za to braki i przypadki gorszace, bo one rażq. Sformułowano też postulat: Trzeba oddzielać Kościól i jego oficjalną "przemyślanq" naukę od wypowiedzi niektórych duchownych, którzy sq nieodpowiedzialni albo niedojrzali do roli, jaka petniq.

\section{Wierni przyzwalajq na niewłaściwe zachowania}

Jedna $\mathrm{z}$ badanych postulowała większą własną odpowiedzialność za Kościół i duchownych. Według niej niektórzy księża nie postępowaliby niewłaściwie, gdyby nie czuli akceptacji i przyzwolenia - nie tylko przełożonych, ale także wierzących: Przyczyna [niektórych zachowań księży] tego jest to, że my to akceptujemy i nie staramy się temu jakoś przeciwdziatac [...] gdy ja bytam w kosiciele i ustyszatam to kazanie, to ja po prostu wysztam..., ale nikt [inny] nie wyszedt z tego kościota. Powyższa sytuacja, w której zdaniem badanej należało zaprotestować, dotyczyła braku szacunku dla innych grup społecznych, a także „zbyt politycznego" kazania.

\section{Różne wymiary doświadczania wartości w wychowaniu chrześcijańskim}

Odwołując się do przeprowadzonej wcześniej analizy sposobów doświadczania wartości w życiu człowieka w opinii studentów (por. Ryc. 1), można spróbować określić, w jaki sposób wychowanie chrześcijańskie i działania Kościoła wspierają doświadczanie wartości. Pod uwagę zostały wzięte przede wszystkim te wartości, które były przedmiotem dyskusji badanych, a które związane są z problemem materializmu i rozumienia wolności. Jak zostało to przedstawione wcześniej, wartości mogą być doświadczane w różnych wymiarach życia i działania człowieka. W niniejszym opracowaniu, na podstawie 
wypowiedzi studentów, wyróżniono cztery. Są to: subiektywny świat przeżyć, działanie w kontekście wartości i dla wartości - trud wybierania, wybory innych jako znak i wzór, doświadczenie zagrożenia wartości (por. Ryc. 1).

\section{Subiektywny świat przeżyć dotyczq̨cy wartości}

Najważniejszy w doświadczaniu wartości jest wewnętrzny subiektywny świat jednostki. Wybory człowieka poprzedza refleksja, przywołanie zinternalizowanych wcześniej określonych wartości, ukształtowanej własnej ich hierarchii. Chrześcijańskie wychowanie pomaga w refleksyjności, dostarcza bogatego zasobu treści, wartości i wzorów, począwszy od źródeł w Biblii i Tradycji, przez świętych po współczesne postacie, formuje moralną postawę wierzącego, stawia wymagania. Poprzez różne formy nauczania i formacji inspiruje i wspiera subiektywny świat przeżyć jako podstawową formę doświadczania wartości.

W tej przestrzeni ma miejsce także odziaływanie negatywne, a czasem brak oczekiwanego oddziaływania. Wpływ negatywny ma miejsce wówczas, gdy duchowni swoim głoszeniem wprowadzają konflikty wartości (np. obrona rodziny poprzez znieważanie osób LGBT). Brak oczekiwanego oddziaływania może polegać na prezentowaniu nieaktualnego obrazu świata i nieumiejętnej analizie współczesnych zjawisk, co sprawia, że przekaz bywa mało przekonujący. Niecierpliwość duchownych wyrażająca się w podkreślaniu nakazów i zakazów oraz piętnowaniu osób odbierane są we współczesnej kulturze wolności i demokracji negatywnie. Brakiem jest także nieumiejętność przeprowadzenia głębokiej analizy i uproszczone ukazywanie problemów związanych z nadmiernym materializmem i konsumpcyjnym stylem życia.

\section{Działanie w kontekście wartości i dla wartości - trud wybierania}

Sferą realizacji wartości i zarazem ich najgłębszego doświadczania są wybory, decyzje i czyny jednostki. Kościół wspiera człowieka w tych wyborach, przede wszystkim tego, kto takiego wsparcia oczekuje i zwraca się po porady duchowe. 
Ważnym miejscem doświadczania wartości są akcje charytatywne, wspólnoty i grupy zjednoczone wokól „wartościowych” celów. Współpraca w realizacji celów jest istotnym wsparciem w doświadczaniu wartości, a także rozwiązywaniu konfliktów wartości oraz przezwyciężaniu kryzysów.

\section{Wybory innych jako znak i wzór}

Kościół stanowi bogaty skarbiec wzorów i znaków. Duchowni realizujący swoje powołanie stanowią taki znak. Uczestnicy wspólnot albo grup realizujących na przykład pomoc dla potrzebujących są znakami wyznawanych wartości i wzorem działania dla innych. Pomagają w refleksji nad wartością wolności (też mogę pomóc, więc powinienem) i nad materialnymi wartościami (pomoc innym promuje wartości osobowe, będące w opozycji do wartości materialnych).

W tej przestrzeni oddziaływania są też znaki i wzory negatywne, chodzi tu o księży zabiegających o dobra materialne, nieszanujących innych ludzi.

\section{Doświadczenie zagrożenia wartości}

Wychowanie chrześcijańskie stanowi wsparcie w sytuacji doświadczania zagrożenia takich wartości jak zdrowie, pokój, bezpieczeństwo, co nieustannie ma miejsce we współczesnym świecie. Wychowanie chrześcijańskie poprzez promowanie wartości niematerialnych może stanowić pomoc w poszukiwaniu sensu życia. Jednakże niektórzy duchowni poprzez swoje nieodpowiedzialne wypowiedzi mogą się przyczyniać do tego, że u poszczególnych jednostek może się rodzić poczucie zagrożenia takich wartości, jak jedność społeczna i narodowa.

\section{Zmiany kulturowe a wspieranie doświadczania i wyboru wartości}

Wartości wpisane w kulturę są stosunkowo trwałe. Jak zauważył Grzegorz Żuk, mają one „moc łączenia ludzi - dają im poczucie wspólnoty i trudno wyobrazić sobie procesy edukacyjne bez wartości 
wspólnych, stanowiących podstawę grupowej tożsamości”(2016: 93). System wartości znajduje się jednak „pod silnym wpływem czasu społecznego", dlatego istotne jest w jakim środowisku i w jakim czasie wychowuje się człowiek (Oleszkowicz, Senejko 2013: 242).

Zmiana jest cechą kultury. Od końca XIX wieku zmiany zachodzą bardzo szybko. W latach 60. ubiegłego wieku w Stanach Zjednoczonych to "filozofia życia” była ważna dla $80 \%$ studentów, gdy tymczasem materialny dobrobyt wskazywany był jako wartość na 5-6 miejscu. W latach 90. ten układ wartości został odwrócony (Oleszkowicz, Senejko 2013: 242). Orientacje moralne Polaków na początku nowego stulecia badał Janusz Mariański. Zdiagnozował on „znaczną niechęć młodego i starszego pokolenia do trwałych, niezmiennych wartości i norm moralnych, z drugiej strony zaś stosunkowo upowszechnione postawy kompromisowe" (2004: 326).

W ponowoczesnej kulturze wolności „wartości współzawodniczą ze sobą i żadna z nich nie jest całkowicie bezpieczna" (Mariański 1998: 85), bowiem zasady skuteczności i pragmatyzmu, kryteria zysku i pieniądza nie łączą się z odmienną „logiką wiary”, z wiernością Bogu, z miłością bliźniego, która wymaga bezinteresowności (Mariański 2004: 323). Wśród wartości społecznych w kulturze Zachodu istotnymi stały się pluralizm, tolerancja i demokracja. Dominują tak zwane wartości osobiste: zdrowie, sukces i przyjemność. Zaczyna brakować wartości absolutnych, które stanowiłyby trwałe punkty odniesienia (Żuk 2016: 94, 116). Tymczasem brak norm i wartości uniwersalnych sprawia, że „zostają zachwiane podstawy do rozstrzygnięć o charakterze wartościującym" (Mariański 2004: 327). Dlatego dzisiaj człowiek stanowi „ostateczną instancję dla samego siebie”, doświadczając zarazem aksjologicznego chaosu (Żuk 2016: 107-108).

Zmiany związane z globalizacją i technicyzacją życia nierzadko prowadzą do konfliktów doświadczanych przez młodych w procesach kształtowania osobistego systemu wartości i budowania tożsamości. Oleszkowicz i Senejko zauważyły jednak, że badania nad przemianami systemu wartości młodzieży nie są zgodne i nie jest łatwo je interpretować (2013: 244, 251).

Bogusław Żurakowski zwrócił uwagę na „zasadniczą antynomię" między hierarchią wartości świata dzieci i młodzieży a wartościami dorosłych i całej kultury. Jak wynika ze specyfiki rozwoju człowieka, „dziecięca struktura aksjologiczna preferuje wartości 
przyjemnościowe. U dziecka wartość zabawy-przyjemności ulokowana jest na najwyższym szczeblu hierarchii aksjologicznej, to jest tam, gdzie zwykle widzimy wartość sacrum" (2005: 279, 286). Badania pokazują, że skupienie na celach materialnych nie przynosi jednak szczęścia, materialiści są często mniej szczęśliwi, mają „obniżony poziom satysfakcji z życia”, a młodzież zamieszkująca najbardziej prestiżowe dzielnice i rejony jest najmniej szczęśliwa (Zawadzka 2006: 62; Oleszkowicz, Senejko 2013: 131).

Oleszkowicz i Senejko scharakteryzowały dwa odmienne systemy motywacji człowieka. Pierwszy ukierunkowany jest na przyjemność, którą osiąga on poprzez konsumpcję, relaks, odpoczynek. Drugi system motywacji skłania do osiągania satysfakcji, jej realizacja może wymagać wysiłku, czasu, a nawet znoszenia nieprzyjemności. Jednak doznawana satysfakcja jest dużo głębszym i bardziej uszczęśliwiającym doświadczeniem, a jej realizacja prowadzi do wewnętrznego rozwoju osoby (por. Oleszkowicz, Senejko 2013: 130). Wiedza o systemach motywacji dziecka stanowi ważny punkt odniesienia. Ważne jest umiejętne wspieranie dziecka, aby pozwolić i pomóc mu „wyrastać z materializmu” i poszukiwania przyjemności, wprowadzając raczej na drogę osiągania satysfakcji. Kluczowe w tym będzie doświadczanie na różne sposoby przez młodych wartości.

Strategiczna w realizacji tego zadania jest rola wychowania. $\dot{Z u k}$ uważa że w sytuacji, gdy w świecie trwają zmagania o pozyskiwanie ludzi dla określonych idei, wychowanie powinno mieć rolę szczególną. Ma być z założenia bezstronne, wspomagające wychowanków $\mathrm{w}$ poznawaniu i interioryzowaniu wartości uniwersalnych, ponadczasowych (2016: 114).

Ważną rolę w tym procesie pełni Kościół. Mimo że sam jest naznaczony współczesnymi kryzysami (materializm, zaangażowanie polityczne), to jednak zachowuje i przekazuje mocno ugruntowane w Tradycji wartości nie tylko religijne, ale i uniwersalne, takie jak życie ludzkie, prawda, wolność, miłość i solidarność. Ważną rolę i zadania Kościoła w przezwyciężaniu kryzysu i nadawaniu sensu dostrzega Alina Chyczewska (2010: 246-248).

Proces wychowywania w odniesieniu do wartości rozpoczyna się od „rozpoznania wartości” (por. Marek 2014: 123). Jednak konieczna jest zmiana systemu kształcenia i wychowania, gdyz - jak zauważyła Krystyna Ostrowska (2005) - sama informacja o wartościach 
nie będzie skuteczna. „Docieranie z dorosłym «światem» wartości do wychowanka” jest niełatwym zadaniem, wyłania się z niego „problem pedagogicznej komunikacji” (Żurakowski 2005: 287).

Potrzebne są więc zmiany w myśleniu wychowawców. Mariański zwrócił uwagę na przemiany społeczno-kulturowe, na swoiste przewartościowanie wartości, jakie się dokonało „w odchodzeniu od wartości powinnościowych do wartości samorealizacyjnych" i na swoistą społeczną ewolucję "od moralności nakazów i zakazów, w kierunku moralności indywidualnych osądów (moralność wolności)" (2004: 332). Właśnie $z$ tego powodu $w$ wychowaniu młodych ważne jest „dostarczanie kryteriów umożliwiających posługiwanie się informacją w celu twórczego «budowania siebie» i świata” (Ostrowska 2005: 303). Dlatego Kościół nie może owocnie prowadzić formacji „starymi” metodami. Potrzebne są różne formy doświadczania wartości w celu identyfikacji z nimi. Młodemu człowiekowi muszą zostać stworzone warunki do zdobywania zarówno wiedzy, jak i wstępnych doświadczeń, aby mógł wygenerować własne refleksje, tak by w efekcie potrafił doświadczać bardziej złożonych przeżyć aksjotycznych, o których pisała Zofia Majewska. By zdołał stanąć wobec koniecznych wyborów życiowych, dylematów, w których nie ma dobrego wyboru, w których - jak podkreśliła Majewska - „zawieszone są uniwersalne reguły moralności” wyboru między dobrem a złem (2010: 94-95), nie dlatego, że przestały obowiązywać, ale z powodu niemożności ich zastosowania, ich nieprzystawalności do sytuacji. Dopiero realizacja wartości poprzez różnego rodzaju wybory, poprzedzone namysłem, określa życiową postawę, kształtuje człowieka, a nawet może „przesądzać o jego wewnętrznym rozwoju” - jak zauważył Janusz Homplewicz (1996: 142).

\section{Konkluzja}

Przed wychowaniem chrześcijańskim stoi poważne wyzwanie. Przed duchownymi, katechetami stoi zadanie nauczenia się rozmowy z ludźmi ceniącymi osobistą wolność i niezależność. Hierarchiczna struktura Kościoła, przede wszystkim określająca relacje kleru między sobą, sprawia, że czasem księża te relacje przenoszą na kontakty $\mathrm{z}$ wierzącymi. Zderzają się jednak $\mathrm{z}$ innymi oczekiwaniami wierzących, z żądaniem dialogu i uszanowania ich zdania. Bez zmiany tego 
nastawienia nie da się w dzisiejszej kulturze wychowywać, formować młodych (ani dorosłych), którzy prawdopodobnie odejdą, a Kościół będzie tracił możliwość wychowawczego oddziaływania. Podczas wywiadu fokusowego pewna studentka mówiła o nieodpowiedzialnych słowach księdza $z$ wiejskiej parafii. Wymieniła kilka kwestii poruszonych przez niego, po czym stwierdziła, że nie wie, o czym mówił potem, bo ja już wysztam z tego kościota. To symboliczne słowa.

Bywa że młodzi prezentują postawę niespójną, po części konsumencką. Z jednej strony oczekują wysokiej jakości „usług religijnych”, traktowania „Z szacunkiem” oraz usuwania wszystkiego, co niewygodne, trudne i niemiłe, co jest postawą typowo konsumencką (por. Ritzer 2004: 296, 299), z drugiej natomiast protestują przeciw materializmowi duchownych i konsumpcjonizmowi w parafiach.

Konsumpcjonizmem i materializmem jesteśmy naznaczeni wszyscy, wszyscy też chcemy być wolni od wszelkich ograniczeń - wychowywani i wychowawcy. Prawdziwym wyzwaniem dla bardziej świadomego problemu wychowawcy jest własne przekraczanie materializmu, aby dać znak i wzór wychowywanym. Może wspólnie z nimi podejmować akty takiego przezwyciężania materializmu poprzez działania prospołeczne i kulturalne wraz z refleksją nad negatywnymi, osobistymi i społecznymi konsekwencjami konsumpcjonizmu. Dyskusje o trudnych wyborach i związanych z nimi emocjach i przeżyciach, próby podejmowania nawet symbolicznych wspólnych działań w obronie wartości zagrożonych - są to podstawowe działania wprowadzające młodych w świat wartości poprzez różne formy ich doświadczania.

Nikt nie zaprzeczy, że wartości są niezwykle ważne w budowaniu własnej i społecznej tożsamości. Problemem dzisiaj jest zmieniający się bardzo szybko świat, kultura i cywilizacja, co wymaga poszukiwania szybkich dróg przystosowania, mogą tracić na tym wartości. Wartości nie da się jednak „chronić”, głośno protestując, że są odrzucane, będzie to tylko wyrazem bezsilności. Trzeba dla nich znajdować nowe przestrzenie w zmieniającej się kulturze i nowe formy ich realizacji. Aby „uchronić”, trzeba znaleźć dla nich miejsce, rolę i znaczenie w zmienionej rzeczywistości, współczesne formy ich urzeczywistniania. Jedynie w taki sposób będą żyły i mogą zostać przekazane kolejnym pokoleniom. 


\section{Bibliografia}

CBOS (2019). Rodzina - jej znaczenie i rozumienie, „Komunikat z badań” nr 2019/22, s. 1-9, https://cbos.pl/SPISKOM.POL/2019/K_022_19. PDF [dostęp: 20.12.2019].

Chałas K. (2003). Wychowanie ku wartościom. Godnośc, wolność, odpowiedzialność, tolerancja, t. 1, Kielce: Wydawnictwo Jedność.

Chałas K. (2018). Edukacja aksjologiczna i wychowanie ku wartościom podstawa budowania szkoty jako wspólnoty życia, pracy i stużby, „Prima Educatione", nr 2, s. 11-22.

Chyczewska A. (2010). Rodzina a przezwyciężanie kryzysów wartości zwiqzanych z sensem życia w okresie adolescencji, [w:] W. Muszyński (red.), Wartości w rodzinie: ciagtośc $i$ zmiana, Toruń: Wydawnictwo Adam Marszałek, s. 243-256.

Dekret o wychowaniu chrześcijańskim Gravissimum educationis. Tekst polski za: Sobór Watykański II. (2002). Konstytucje. Dekrety. Deklaracje. Poznań: Pallottinum, s. 314-324.

Dziekoński S. (2000). Wychowanie w nauczaniu Kościoła. Od wieku XIX do Soboru Watykańskiego II, Warszawa: Wydawnictwo UKSW.

Homplewicz J. (1996). Etyka pedagogiczna, Rzeszów: Wydawnictwo Wyższej Szkoły Pedagogicznej.

KANTAR, Polacy o oszczędzaniu. Grudzień 2019, http://www.tnsglobal.pl/archiwumraportow/files/2019/12/K.059_Stosunek-do-pieni\%C4\%99dzy_O011a-19.pdf [dostęp: 1.01.2020].

Kowalczyk S. (2006). Cztowiek w poszukiwaniu wartości. Elementy aksjologii personalistycznej, Lublin: Wydawnictwo KUL.

Łaciak B. (2011). Komercyjne przemiany wspótczesnego dzieciństwa, [w:] B. Eaciak (red.), Nowe spoteczne wymiary dzieciństwa, Warszawa: Wydawnictwo Akademickie „Żak”, s. 77-112.

Łobocki M. (1993). Pedagogika wobec wartości, [w:] B. Śliwerski (red.), Kontestacje pedagogiczne, Kraków: Oficyna Wydawnicza „Impuls”.

Majewska Z. (2010). Problemy doświadczania i istnienia wartości. W kregu myśli Edmunda Husserla i Romana Ingardena, Lublin: Wydawnictwo UMCS.

Mariański J. (1998). Kościót katolicki w spoteczeństwie obywatelskim, Lublin: Redakcja Wydawnictw KUL.

Mariański J. (2004). Religijność spoteczeństwa polskiego w perspektywie europejskiej. Próba syntezy socjologicznej, Kraków: Zakład Wydawniczy „Nomos”.

Marek Z. (2014). Religia - pomoc czy zagrożenie dla edukacji?, Kraków: Wydawnictwo WAM.

Matusewicz C. (1975). Psychologia wartości, Warszawa: Państwowe Wydawnictwo Naukowe.

Melosik Z., Szkudlarek T. (2010). Kultura, tożsamość i edukacja. Migotanie znaczeń, Kraków: Oficyna Wydawnicza „Impuls”. 
Miczyńska-Kowalska M. (2010). Rodzina w procesie przekazywania wartości, [w:] W. Muszyński (red.), Wartości w rodzinie. Ciagtość i zmiana, Toruń: Wydawnictwo Adam Marszałek, s. 75-84.

Niewęgłowski J. (2005). Kościót i wychowanie. Zarys problematyki, „Seminare”, nr 21, s. 453-460.

Oleszkowicz A., Senejko A. (2013). Psychologa dorastania. Zmiany rozwojowe w dobie globalizacji, Warszawa: Wydawnictwo Naukowe PWN.

Ostrowska K. (2005). Wychowywać do urzeczywistniania wartości, [w:] F. Adamski (red.), Wychowanie personalistyczne, Kraków: Wydawnictwo WAM, s. 291-306.

Ritzer G. (2004). Magiczny świat konsumpcji, przeł. L. Stawowy, Warszawa: Wydawnictwo Literackie Muza SA.

Rynio A. (2017). Tradycyjne i wspótczesne środowiska wychowania chrześcijańskiego, [w:] A. Walulik, J. Mółka (red.), Septuaginta pedagogiczno-katechetyczna. Ksiega jubileuszowa dedykowana Księdzu Profesorowi dr. hab. Zbigniewowi Markowi SJ w siedemdziesiąta rocznice urodzin, Kraków: Akademia Ignatianum w Krakowie, s. 369-388.

Tchorzewski A.M. de (2017). Autorytet i jego struktura aksjologiczna, „Studia Paedagogica Ignatiana”, t. 20, nr 5, s. 187-212.

TNS Polska, Świat się zmienia. Maj 2013, http://www.tnsglobal.pl/archiwumraportow/files/2014/03/K.033_Zmiana-swiata_O04a-13.pdf [dostęp: 1.01 .2020$]$.

Wajsprych D. (2009). Wychowanie chrzescijanskie w świetle literatury i dokumentów Kościota u progu trzeciego tysiąclecia - perspektywy rozwojowe, „Paedagogia Christiana”, nr 23(1), s. 11-25.

Zawadzka A.M. (2006). Wartości osobiste ttumaczqce orientację materialistycznq jednostki, „Roczniki Psychologiczne” t. 9, nr 2, s. 61-80.

Żuk G. (2016). Edukacja aksjologiczna. Zarys problematyki, Lublin: Wydawnictwo UMCS.

Żurakowski B. (2005). Wychowanie do wyboru wartości, [w:] F. Adamski (red.), Wychowanie personalistyczne, Kraków: Wydawnictwo WAM, s. 279-289.

\section{ADRES DO KORESPONDENCJI}

Dr hab. Renata Jasnos, prof. AIK

Akademia Ignatianum w Krakowie

Wydział Pedagogiczny

Instytut Nauk o Wychowaniu

e-mail: renata.jasnos@ignatianum.edu.pl 